\title{
Research Article: Studies on crop load, fruit thinning and their effects on growth attributes of guava (Psidium guajava L.) cV. ALLAHABAD SAFEDA under meadow planting system
}

Article Chronicle:

Received :

13.07.2017;

Accepted :

28.07.2017

KEY WoRds :

Shoot length, Leaf area index, Thinning, Crop load
Author for correspondence :

\section{PRABHUGOUDA PATIL}

Department of

Horticulture (Fruit

Science), Sri Konda

Laxman Telangana State

Horticulture University,

HYDERABAD

(TELANGANA) INDIA

See end of the article for

authors' affiliations

\section{arABHUgOUdA PATIL, A. KirAN KUMAR, A. BHAGWAN ANd M. SREEDHAR}

SUMMARY : The study was carried out at the Fruit research station, Sangareddy, Telangana, Sri Konda Laxman Telangana State Horticulture University, Hyderabad during the period of October, 2016 to February, 2017 (Hasta bahar crop) to find out the effect of fruit thinning on growth attributes of guava (Psidium guajava L.) cv. ALLAHABAD SAFEDA under meadow planting system. The treatments of the experiment were crop load levels i.e. retaining of 5, 10, 15, 20 fruits per plant and control (No thinning) and second factor as a observations recorded after fruit thinning i.e. (i) 30 days after fruit set (ii) 60 days after fruit set (iii) 90 days after fruit set and at the time of harvest. The ages of the plants were 4-5 years. Results revealed that the significant differences were noticed in guava cv. ALLAHABAD SAFEDA for different vegetative and fruit growth parameters studied in hasta bahar crop. There is an increasing trend during growth and development in shoot length, leaf area index, and fruit growth parameters like fruit length, fruit diameter and average fruit weight. At the time of harvest recorded maximum shoot length $(47.88 \mathrm{~cm})$, leaf area index (1.09), fruit length $(6.34 \mathrm{~cm})$, fruit diameter $(6.92 \mathrm{~cm})$ and average fruit weight $(175.40 \mathrm{~g})$. The interaction between days after fruit set and fruit load has shown significant results that, at the time of harvest with 15 fruits per plant recorded best result in shoot length $(52.06 \mathrm{~cm})$ and in fruit growth parameters, maximum fruit length $(7.34 \mathrm{~cm})$, fruit diameter $(4.46 \mathrm{~cm})$ and fruit weight $(236.46 \mathrm{~g}$ ) was recorded in 5 fruits per plant at the time of harvest.

How to cite this article : Patil, Prabhugouda, Kumar, A. Kiran, Bhagwan, A. and Sreedhar, M. (2017). Studies on crop load, fruit thinning and their effects on growth attributes of guava (Psidium guajava L.) cv. ALLAHABAD SAFEDA under meadow planting system. Agric. Update, 12(TECHSEAR-3) : 804-811; DOI: 10.15740/HAS/ AU/12.TECHSEAR(3)2017/804-811. 